\title{
Związek zaangażowania w studiowanie i wypalenia studiami z osiągnięciami akademickimi
}

\begin{abstract}
This study addresses the question how students' engagement and burnout are related to academic achievement - the grade point average and the number of passed exams. The study involved 205 students. Multiple regression analysis indicated that burnout is direct significant predictor of grade point average, but the engagement is not. Relation between students' engagement and the grade point average was mediated by level of burnout. Further analysis revealed that students who have passed all the exams in the first term were characterized by lower level of burnout than students who have not passed all the exams in the first term. However, students from both groups did not differ, in the level of study engagement. The results indicate that high academic achievement is related to the lack of a burnout rather than the presence of engagement. Results also show that the grade point average and the number of passed exams are poor indicators of the level of students' engagement.
\end{abstract}

\section{Key words:}

engagement, burnout, academic achievement, grade point average

1 Konrad Kulikowski, Instytut Psychologii, Uniwersytet Jagielloński w Krakowie, Polska, konrad.kulikowski@doctoral.uj.edu.pl. 


\section{WSTĘP}

W powszechnym przekonaniu zaangażowanie w studiowanie jest czynnikiem wiążącym się z sukcesami akademickimi. Student zaangażowany utożsamiany bywa ze studentem odnoszącym sukcesy, a samo zaangażowanie w każdej niemal instytucji edukacyjnej jest wysoko cenione (Dunne, Owen, 2013). W istocie wiele badań wskazuje na związek zaangażowania uczniów i studentów z sukcesami osiąganymi w nauce. Zaangażowanie w szkole średniej wiąże się z sukcesem w rekrutacji na studia, podczas gdy wypalenie jest predyktorem opóźnionego ukończenia szkoły (Vasalampi, Salmela-Aro, Nurmi, 2009). Wśród wysoce zaangażowanych obserwuje się mniejsze ryzyko przedwczesnego zaprzestania nauki (drop out) (Janosz, Archambault, Morizot, Pagani, 2008). Zaangażowanie behawioralne, definiowane jako wytrwałość i wysiłek wkładany w naukę, pozytywnie wiąże się z wynikami w testach czytania (Jung-Sook, 2014). Jednak, jak podkreślają Trowler i Trowler (2010), termin zaangażowanie niesie ze sobą wiele znaczeń i bywa rozmaicie rozumiany, co nie ułatwia określenia rzeczywistego związku zaangażowania w studiowanie z osiągnięciami akademickimi. Sytuację komplikuje fakt, iż obecnie brak jednoznacznej definicji zaangażowania w studiowanie (por. Fredricks, Blumenfeld, Paris, 2004; Leacha, Zepkea, 2011; Wang, Degol, 2014) i wypalenia studiami (por. Hazel, Vazirabadi, Albanes, Gallagher, 2014; Maroco, Bonini, 2012).

Na potrzeby prowadzonych badań zaangażowanie w studiowanie i wypalenie studiami zdefiniowano za Schaufelim, Martinezem, Pinto, Salanovą i Bakkerem (2002). Autorzy ci, opisując funkcjonowanie studentów, bazują na dobrze zbadanych pojęciach wypalenia zawodowego (Chirkowska-Smolak, Kleka, 2011; Maslach, Schaufeli, Leiter, 2001; Schaufeli, Taris, 2005; Schaufeli, Leiter, Maslach, 2009) oraz zaangażowania w pracę (Schaufeli, Bakker, 2004; Schaufeli, Bakker, Salanova, 2006). Wypalenie studiami definiowane jest przez nich jako wyczerpanie wymaganiami, jakie stawiają studia, przyjmowanie cynicznej postawy i dystansowanie się od przedmiotu studiów oraz przekonanie o braku kompetencji i osiągnięć w studiowaniu. Z kolei zaangażowanie w studiowanie to pozytywny stan umysłu charakteryzowany przez wigor, poświęcenie się (dedication) studiom oraz zaabsorbowanie studiami. Wigor opisywany jest przez wysoki poziom energii i chęć wkładania wysiłku w podejmowaną pracę. Poświęcenie się rozumiane jest jako przekonanie o znaczeniu studiów, entuzjazm wobec nich, inspirowanie się nimi oraz duma z ich powodu. Zaabsorbowanie to pełna koncentracja i poznawcze pogrążenie się w wykonywanych zadaniach. Teoretycznymi ramami dla przyjętych koncepcji wypalenia i zaangażowania może być zaadaptowany do warunków akademickich model wymagań i zasobów pracy (Job-Demands Resources, Bakker 
i Demerouti, 2014). Model ten ujmuje zaangażowanie i wypalenie jako efekt oddziaływań wymagań i zasobów obecnych w środowisku. Salmela-Aro i Upadyaya (2014) w badaniach longitudinalnych wykazali, iż wymagania stawiane przez szkołę pozwalają przewidywać wypalenie, zasoby natomiast wiążą się z zaangażowaniem.

Schaufeli i in. (2002) wskazali na możliwość trafnego pomiaru zaangażowania i wypalenia zgodnie z proponowanymi przez siebie definicjami oraz na pozytywną korelację zaangażowania i negatywną wypalenia z liczbą egzaminów zdanych w pierwszym terminie. Zhang, Gan i Cham (2007) potwierdzili trafność omawianego sposobu pomiaru wypalenia i zaangażowania wśród chińskich studentów. Ponadto zauważyli, iż wypalenie wiązało się z nieadaptacyjnym perfekcjonizmem, charakteryzującym się obieraniem nierealnych celów, a zaangażowanie z perfekcjonizmem pozytywnym, cechującym się wytrwałością w dążeniu do realistycznych celów. Także Hu i Schaufeli (2009) dowiedli trafności trójczynnikowej struktury wypalenia studiami. Dalsze badania wskazują, iż zaangażowanie w studia może być postrzegane jako mediator relacji pomiędzy zasobami, jakie studia dają, a aktywnością podczas zajęć, z kolei aktywność podczas zajęć pozytywnie wiąże się z uzyskiwanymi ocenami (Bakker, Sanz Vergel, Kuntze, 2014). Salanova, Schaufeli, Martinez i Breso (2010) wykazali mediacyjną rolę zaangażowania dla związku pomiędzy czynnikami ułatwiającymi (facilitators) naukę a ocenami uzyskiwanymi przez studentów na koniec semestru, nie wykazali jednak związku pomiędzy wypaleniem a ocenami. Natomiast w badaniach Yang (2004) wypalenie było negatywnym predyktorem średniej ocen tajwańskich studentów.

W świetle dostępnych badań wydaje się, iż związek wypalenia studiami i zaangażowania w studia z osiągnięciami akademickimi jest zagadnieniem wciąż mało jeszcze poznanym i dyskusyjnym. Zatem za główny cel prowadzonych badań przyjęto próbę odpowiedzi na pytanie, w jaki sposób zaangażowanie w studia i wypalenie studiami wiążą się z osiągnięciami akademickimi.

\section{BADANIA WŁASNE}

\subsection{BADANA GRUPA}

Rekrutację badanych prowadzono za pośrednictwem portalu Facebook, a badanie miało formę kwestionariusza online. Zdecydowano się wykorzystać taki sposób dystrybucji ankiet, ponieważ 97\% Polaków w wieku 16-24 oraz 88\% w wieku 25-34 korzysta z Internetu (Batorski, 2013). Co więcej, 92\% internautów w wieku 
18-24 i 78\% w wieku 24-34 jest zarejestrowanych na portalach społecznościowych (CBOS, 2014). Informację o badaniu rozsyłano losowym użytkownikom portalu w wieku od 20 do 30 lat. Wiadomość dotarła do 27504 użytkowników portalu, z tego 411 rozpoczęło wypełnianie kwestionariusza. Ostatecznie w analizie uwzględniono odpowiedzi udzielone przez 205 studentów (176 kobiet, 85,6\%), średnia wieku badanych wyniosła 21,6 lat (SD 1,8). Pomimo licznej obecności studentów na portalach społecznościowych należy zauważyć, iż badana grupa internautów nie jest reprezentatywna dla ogółu polskich studentów. Studenci pierwszego roku stanowili 19\% (39 osób), studenci drugiego roku 51\% (104osób), trzeciego roku 19\% (39 osób), czwartego roku 4\% (8 osób), a studenci piątego roku 7\% (15 osób) badanych. Nie wykazano istotnych statystycznie różnic w poziomie zaangażowania $(\mathrm{F}(4,200)=1,79, \mathrm{p}=0,132)$ oraz wypalenia $(\mathrm{F}(4,200)=1,79$, p=0,132) ze względu na rok studiów. Większość, 60\% (123 osób) badanych, byli to studenci kierunków o profilu humanistycznym, 27\% (56 osób) badanych studenci kierunków ścisłych, a 12\% (25 osób) kierunków medycznych. Profil studiów nie wykazywał związku z zaangażowaniem $(\mathrm{F}(2,201)=0,16, \mathrm{p}=0,856)$ i wypaleniem $(F(2,201)=2,6, p=0,077)$. Spośród badanych 27\% (56 osób) deklarowało, iż jednocześnie pracuje i studiuje, nie wykazano różnic w poziomie zaangażowania $(\mathrm{t}=1,69$, $\mathrm{df}=203, \mathrm{p}=0,091)$ i wypalenia $(\mathrm{t}=-0,25, \mathrm{df}=203, \mathrm{p}=0,802)$ pomiędzy studentami pracującymi i niepracującymi.

\subsection{STOSOWANE NARZĘDZIA}

Pomiar zaangażowania i wypalenia studiami przeprowadzono analogicznie jak w badaniach Schaufeliego i in. (2002). Badając zaangażowanie i wypalenie wśród studentów, Schaufeli i in. (2002) używali zmodyfikowanych wersji kwestionariuszy do pomiaru zaangażowania w pracę UWES i wypalenia zawodowego MBI. Modyfikacja polegała na zmianie w kwestionariuszach słów odnoszących się do pracy na słowa dotyczące nauki lub studiowania: For instance, the item "I feel emotionally drained from my work [italics added]" was rephrased in "I feel emotionally drained from my study [italics added] (Schaufeli i in., 2002, s. 467)”. W prezentowanych badaniach zastosowano taką samą modyfikację: polskie adaptacje kwestionariusza UWES (Szabowska-Walaszczyk, Zawadzka, Wojtaś, 2011) oraz MBI (Chirkowska-Smolak, Kleka, 2011) nieznacznie zmodyfikowano w taki sposób, że słowa praca zamieniono na słowa związane z nauką lub studiowaniem. Przykładowo, oryginalne pytanie skali UWES Podczas pracy czuję sie psychicznie odporny(a) zmieniono na Podczas nauki czuję się psychicznie odporny(a), a pytanie skali MBI Moja praca sprawia, że czuję się emocjonalnie wyczerpany(a) 
zamieniono na Moje studia sprawiajq, że czuję się emocjonalnie wyczerpany(a). Brzmienie poszczególnych pytań i szczegółowe właściwości psychometryczne stosowanych narzędzi prezentowane są w tabelach 1 oraz 2.

Zaangażowanie $w$ studiowanie - Przeprowadzona eksploracyjna analiza czynnikowa (rotacja varimax znormalizowana) i analiza rzetelności zebranych danych wskazała na zadowalającą trafność i rzetelność dwuczynnikowej struktury kwestionariusza mierzącego zaangażowanie w studiowanie. Wyróżnione dwa wymiary zaangażowania to: zaabsorbowanie studiami (5 itemów; $M=12,6 ; \mathrm{SD}=6,6$; $\alpha$-cronbacha $=0,84$ ) oraz poświęcenie się studiom (5 itemow; $M=17,4 ; \mathrm{SD}=8,0$; $\alpha$-cronbacha $=0,93$ ), obliczono także wynik całkowity w skali zaangażowania (M=30,0; SD=13,0; $\alpha$-cronbacha=0,91). Szczegółowy opis pytań wchodzących w skład zastosowanego kwestionariusza zaangażowania w studiowanie przedstawia tabela 1.

Tab. 1. Pytania wchodzące $w$ skład skal kwestionariusza zaangażowania w studiowanie wraz z mocą dyskryminacyjną i ładunkiem czynnikowym danego pytania

\begin{tabular}{|c|c|c|c|}
\hline & \multicolumn{2}{|c|}{ Ładunek czynnikowy } & \multirow{2}{*}{$\begin{array}{c}\text { Moc } \\
\text { dyskry- } \\
\text { minacyjna* }\end{array}$} \\
\hline & $\begin{array}{l}\text { Poświę- } \\
\text { cenie }\end{array}$ & $\begin{array}{l}\text { Zaabsor- } \\
\text { bowanie }\end{array}$ & \\
\hline Podczas nauki czuję się psychicznie odporny(a) & 0,17 & $\mathbf{0 , 8 1}$ & 0,67 \\
\hline Mogę uczyć się bez przerwy przez bardzo długi czas & 0,44 & 0,68 & 0,68 \\
\hline Czas szybko płynie, kiedy się uczę & 0,31 & 0,62 & 0,55 \\
\hline Czuję się szczęśliwy(a), kiedy intensywnie się uczę & 0,36 & 0,74 & 0,71 \\
\hline Zapominam o wszystkim dokoła, kiedy się uczę & 0,09 & 0,79 & 0,59 \\
\hline Moje studia są dla mnie wyzwaniem & 0,86 & 0,29 & 0,85 \\
\hline Moje studia są dla mnie pełne sensu i celowości & 0,84 & 0,27 & 0,82 \\
\hline Moje studia są dla mnie inspirujące & $\mathbf{0 , 8 7}$ & 0,32 & 0,88 \\
\hline $\begin{array}{l}\text { Jestem entuzjastycznie nastawiony(a) do swoich } \\
\text { studiów }\end{array}$ & 0,84 & 0,28 & 0,83 \\
\hline $\begin{array}{l}\text { Jestem dumny(a) z kierunku studiów, który wybra- } \\
\text { łem(am) }\end{array}$ & 0,84 & 0,17 & 0,78 \\
\hline
\end{tabular}

* Moc dyskryminacyjna pozycji - korelacja pomiędzy pytaniem a wynikiem skali, w skład której to pytanie wchodzi, przy wyłączeniu z tej skali danego pytania, $\mathrm{N}=205$.

Źródło: Opracowanie własne.

Wypalenie studiami - Na podstawie przeprowadzonej eksploracyjnej analizy czynnikowej zebranych danych (rotacja varimax znormalizowana) za trafną uznano trójczynnikową strukturę kwestionariusza do pomiaru wypalenia studiami. 
Wyróżniono następujące wymiary wypalenia: wyczerpanie (3 itemy; $M=9,7$; $\mathrm{SD}=4,1 ; \alpha$-cronbacha $=0,76$ ), brak poczucia osiągnięć zawodowych (3 itemy; $\mathrm{M}=11,7 ; \mathrm{SD}=3,6 ; \alpha$-cronbacha=0,81) oraz cynizm (3 itemy; $\mathrm{M}=8,8 ; \mathrm{SD}=5,0$; $\alpha$-cronbacha $=0,86)$, obliczono także wynik całkowity w skali wypalenia $(\mathrm{M}=24,4$; $\mathrm{SD}=9,4 ; \alpha$-cronbacha=0,81). Szczegółowa analiza pytań wchodzących w skład kwestionariusza wypalenia studiami przedstawia tabela 2.

Tab. 2. Pytanie wchodzące $w$ skład skal wypalenia studiowaniem wraz z mocą dyskryminacyjną i ładunkiem czynnikowym danego pytania

\begin{tabular}{|c|c|c|c|c|}
\hline & \multicolumn{3}{|c|}{ Ładunek czynnikowy } & \multirow{2}{*}{$\begin{array}{c}\text { Moc } \\
\text { dyskry- } \\
\text { minacyjna* }\end{array}$} \\
\hline & $\begin{array}{l}\text { Wyczer- } \\
\text { panie }\end{array}$ & $\begin{array}{c}\text { Brak } \\
\text { poczucia } \\
\text { osiągnięć\# }\end{array}$ & $\begin{array}{l}\text { Cy- } \\
\text { nizm }\end{array}$ & \\
\hline $\begin{array}{l}\text { Moje studia sprawiają, że czuję się emocjo- } \\
\text { nalnie wyczerpany(a) }\end{array}$ & 0,71 & $-0,22$ & 0,44 & 0,63 \\
\hline Po zajęciach jestem totalnie wykończony(a) & 0,84 & 0,05 & 0,06 & 0,54 \\
\hline Studiowanie jest dla mnie stresujące & 0,81 & $-0,25$ & 0,07 & 0,61 \\
\hline $\begin{array}{l}\text { Odczuwam spadek zainteresowania studiami } \\
\text { w stosunku do okresu, kiedy je rozpoczyna- } \\
\text { łem(am) }\end{array}$ & 0,10 & $-0,15$ & 0,87 & 0,75 \\
\hline Czuję, że mój zapał do studiowania wygasa & 0,24 & $-0,20$ & 0,83 & 0,75 \\
\hline Powątpiewam w użyteczność moich studiów & 0,05 & $-0,14$ & 0,86 & 0,70 \\
\hline $\begin{array}{l}\text { Skutecznie rozwiązuję problemy, które } \\
\text { pojawiają się w czasie studiowania }\end{array}$ & $-0,17$ & $\mathbf{0 , 8 0}$ & $-0,26$ & 0,67 \\
\hline $\begin{array}{l}\text { Moim zdaniem jestem dobrym studentem } \\
\text { (studentką) }\end{array}$ & $-0,01$ & 0,83 & $-0,17$ & 0,64 \\
\hline $\begin{array}{l}\text { Wiem, że poradzę sobie ze stawianymi mi } \\
\text { podczas zajęć wymaganiami }\end{array}$ & $-0,16$ & 0,86 & $-0,08$ & 0,68 \\
\hline
\end{tabular}

\#W skali braku poczucia osiągnięć odpowiedzi na wszystkie 3 pytania są odwracane do zliczania wyników, *Moc dyskryminacyjna pozycji - korelacja pomiędzy pytaniem a wynikiem skali, w skład której to pytanie wchodzi, przy wyłączeniu z tej skali danego pytania, N=205.

Źródło: Opracowanie własne.

Analiza korelacji pomiędzy wynikami w poszczególnych skalach (por tab. 3) wskazuje na zgodne z założeniami teoretycznymi (Schaufeli i in., 2002) negatywne korelacje pomiędzy zaangażowaniem i wypaleniem, co może być potwierdzeniem trafności teoretycznej stosowanych narzędzi. 
Tab. 3. Współczynniki korelacji pomiędzy wynikami w skalach wypalenia i zaangażowania studiami

\begin{tabular}{llllllll}
\hline & Zmienne & $\mathbf{1}$ & $\mathbf{2}$ & $\mathbf{3}$ & $\mathbf{4}$ & $\mathbf{5}$ & $\mathbf{6}$ \\
\hline 1 & Zaabsorbowanie & 1,00 & & & & & \\
\hline 2 & Poświęcenie się & 0,61 & 1,00 & & & & \\
\hline 3 & Zaangażowanie (1+2) & 0,88 & 0,91 & 1,00 & & & \\
\hline 4 & Wyczerpanie & $-0,21$ & $-0,28$ & $-0,28$ & 1,00 & & \\
\hline 5 & Cynizm & $-0,53$ & $-0,81$ & $-0,76$ & 0,40 & 1,00 & \\
\hline 6 & Brak osiągnięć & $-0,49$ & $-0,35$ & $-0,47$ & 0,30 & 0,33 & 1,00 \\
\hline 7 & Wypalenie (4+5+6) & $-0,55$ & $-0,67$ & $-0,69$ & 0,75 & 0,82 & 0,66 \\
\hline
\end{tabular}

Wszystkie współczynniki korelacji $r$ Pearsona są istotne dla $\alpha=0,05, N=205$.

Źródło: Opracowanie własne.

Osiągnięcia akademickie - mierzono za Schaufelim i in. (2002) jako odsetek egzaminów zdanych przez badanych w pierwszym terminie sesji zimowej 2015 roku. Badani byli proszeni o podanie całkowitej liczby egzaminów, jakie zdawali, oraz liczby egzaminów, które zdali w pierwszym terminie. Na podstawie tych danych dla każdego badanego obliczano odsetek egzaminów zdanych w pierwszym terminie (M=90,2; SD=18,6). Drugim wskaźnikiem osiągnięć akademickich była średnia ocena uzyskana na zakończenie sesji zimowej 2015 roku deklarowana przez badanych $(M=4,1 S D=0,5)$. Pomiędzy wskaźnikami odnotowano istotną statystycznie korelację o umiarkowanej sile, $\mathrm{R}$ Spearmana $=0,50$. Zmiennością jednego ze wskaźników można tłumaczyć jedynie ok. 25\% zmienności w zakresie drugiego, zatem analiza obu wskaźników wydaje się uzasadniona. Odpowiedzi na pytania o średnią ocen i liczbę zdanych egzaminów nie były wymagane. Badani byli informowani, iż jeśli z jakichś powodów nie chcą odpowiadać na któreś z tych pytań, nie muszą tego robić. Zastosowano taki zabieg, ponieważ pytanie o średnią i zdane egzaminy może być pytaniem wrażliwym, stwarzającym poczucie braku anonimowości. Wskazano (Stieger, Reips, Voracek, 2007), iż wymaganie odpowiedzi w przypadku pytań wrażliwych prowadzi do uzyskiwania odpowiedzi zafałszowanych. Postanowiono zatem zaakceptować ewentualne braki w danych, zachowując jednak przy tym większą ich rzetelność. Informację o średniej ocen podało 158 badanych. Studenci podający średnią ocen nie różnią się poziomem zaangażowania $\mathrm{t}=1,25 ; \mathrm{df}=203 ; \mathrm{p}=0,212$ i wypalenia $\mathrm{t}=-0,20 ; \mathrm{df}=203 ; \mathrm{p}=0,843$ w stosunku do studentów, którzy nie podali średniej. Informację o liczbie zdanych egzaminów podało 155 badanych, z tego 73\% (110 osób) deklarowało, iż zdało wszystkie egzaminy w pierwszym terminie. Rozkład wyników w zakresie odsetka 
egzaminów zdanych w pierwszym terminie znacznie odbiegał od rozkładu normalnego (test Shapiro-Wilka p<0,001; wsp. skośności=-2,12). W związku z tym postanowiono zaklasyfikować badanych do jednej z dwóch grup: studentów, którzy zdali wszystkie egzaminy w pierwszym terminie oraz studentów, którzy nie zdali wszystkich egzaminów. Studenci odpowiadający na pytanie o liczbę zdanych egzaminów nie różnili się poziomem zaangażowania $\mathrm{t}=1,26$; $\mathrm{df}=203$; $\mathrm{p}=0,208$ i wypalenia $\mathrm{t}=-\mathbf{0 , 5 7}$;f=203; $\mathrm{p}=0,563$ w stosunku do studentów, którzy nie podali odpowiedzi.

\subsection{HIPOTEZY BADAWCZE}

W celu uzyskania odpowiedzi na główne pytanie badawcze: W jaki sposób zaangażowanie w studia i wypalenie studiami wiq̨że się z osiq̨gnięciami akademickimi? postawiono trzy szczegółowe hipotezy:

Hipoteza 1 Wzajemne oddziaływanie zaangażowania w studiowanie i wypalenia studiami jest predyktorem średniej ocen uzyskiwanych przez studentów.

Hipoteza 2a Studenci zdający wszystkie egzaminy w pierwszym terminie cechują się wyższym poziomem zaangażowania w studia niż studenci, którzy nie zdali wszystkich egzaminów w pierwszym terminie.

Hipoteza 2b Studenci zdający wszystkie egzaminy w pierwszym terminie cechują się niższym poziomem wypalenia studiami niż studenci, którzy nie zdali wszystkich egzaminów w pierwszym terminie.

\section{WYNIKI}

W celu weryfikacji postawionej hipotezy przeprowadzono serię analiz regresji. W pierwszej kolejności sprawdzono związek potencjalnych zmiennych zakłócających, takich jak: typ studiów (kodowany jako humanistyczne 0/1, ścisłe 0/1, medyczne niekodowany punkt odniesienia), czas poświęcany na naukę, płeć, rok studiów, dodatkowa praca (0/1). Przeprowadzona krokowa analiza regresji wykazała, iż żadna ze zmiennych nie jest istotnym predyktorem średniej ocen.

Do właściwego modelu regresji, by uniknąć współliniowości, włączono ogólne wyniki w skali wypalenia i zaangażowania zamiast wyników w poszczególnych podskalach. W pierwszej kolejności stworzono model, w którym 
średnią ocen wyjaśniono za pomocą zaangażowania w studiowanie. Model ten okazał się być dobrze dopasowany do danych $\mathrm{F}(1,156)=12,4 ; \mathrm{p}<0,001$; $\mathrm{R} 2=7 \%$, im wyższe zaangażowanie $\mathrm{w}$ studiowanie $(\beta=0,226 ; \mathrm{p}<0,001)$, tym wyższa średnia ocen. Następnie stworzono model, w którym średnia ocen była tłumaczona poprzez wypalenie. Model ten również okazał się dobrze dopasowany do danych $\mathrm{F}(1,156)=42,5 ; \mathrm{p}<0,001 ; \mathrm{R} 2=21 \%$ i wskazywał, że im wyższe wypalenie studiami $(\beta=-0,462 ; p<0,001)$, tym niższa średnia ocen. Kolejnym krokiem była budowa modelu, w którym średnia ocen wyjaśniana byłaby poprzez wzajemne oddziaływanie wypalenia i zaangażowania w studiowanie. W modelu tym istotnym predyktorem średniej ocen okazało się jedynie wypalenie studiami ( $\beta=-0,518 ; p<0,001)$, podczas gdy współczynnik regresji dla zaangażowania studiami znacznie zmalał i stał się nieistotny statystycznie $(\beta=-0,081 ; \mathrm{p}=0,401)$. Przy uwzględnieniu wzajemnych oddziaływań pomiędzy wypaleniem studiami i zaangażowaniem w studia tylko wypalenie okazuje się istotnym predyktorem średniej ocen. W związku z tym nie ma podstaw do potwierdzenia postawionej hipotezy badawczej mówiącej, iż wzajemne oddziaływanie zaangażowania w studiowanie i wypalenia studiami jest predyktorem średniej ocen uzyskiwanych przez studentów.

Zanik istotności jednego z predyktorów może wskazywać na występowanie efektu mediacji. Innymi słowy, zaangażowanie może wiązać się ze średnią ocen nie bezpośrednio, ale poprzez oddziaływanie na wypalenie studiami. Aby sprawdzić te przypuszczenia, przeprowadzono testowanie mediacji zgodnie z podejściem zaproponowanym przez Barona i Kenny’ego (1986), wsparte testem Sobela (Bedyńska, Książek, 2012).

Baron i Kenny (1986) zakładają, że o występowaniu mediacji możemy wnioskować, gdy spełnione są trzy warunki: po pierwsze, zmienna niezależna (zaangażowanie) jest istotnym predyktorem zmiennej zależnej (średnia ocen); po drugie, pomiędzy zmienną niezależną (zaangażowanie) a potencjalnym mediatorem (wypalenie) zachodzi istotny związek; po trzecie, w modelu uwzględniającym jednocześnie zmienną niezależną (zaangażowanie) i mediator (wypalenie) oddziaływanie zmiennej niezależnej na zależną staje się nieistotne przy zachowaniu istotnego związku między mediatorem a zmienną zależną.

Przeprowadzone analizy wskazują na spełnienie pierwszego i trzeciego założenia. Zaangażowanie jest istotnym predyktorem średniej ocen, ale w modelu uwzględniającym także wypalenie traci istotność. Pozostała zatem do sprawdzenia istotność relacji pomiędzy zmienną niezależną (zaangażowanie) a potencjalnym mediatorem (wypalenie). Relacja ta okazuje się istotna statystycznie $(\beta=-0,680$; $\mathrm{p}<0,001)$, a stworzony model dobrze dopasowany do danych $\mathrm{F}(1,156)=134,58$ 
$\mathrm{p}<0,000 \mathrm{R} 2=46 \%$. Zatem przeprowadzone analizy regresji wskazują, iż wypalenie studiami może być zmienną pośredniczącą pomiędzy zaangażowaniem studiami a średnią ocen. Dodatkowo wyniki wskazujące na mediację zostały potwierdzone testem Sobela Z=4,96; $\mathrm{p}<0,001$. Zestawienie wyników przeprowadzonych analiz przedstawia rysunek 1 .

W oparciu o zebrane dane i przeprowadzone analizy regresji nie możemy potwierdzić istnienia bezpośredniego związku pomiędzy wypaleniem studiami i zaangażowaniem w studia a średnią ocen. Uzasadnione wydaje się jednak założenie istnienia bezpośredniego negatywnego związku wypalenia ze średnią ocen oraz pośredniego pozytywnego związku zaangażowania ze średnią ocen.

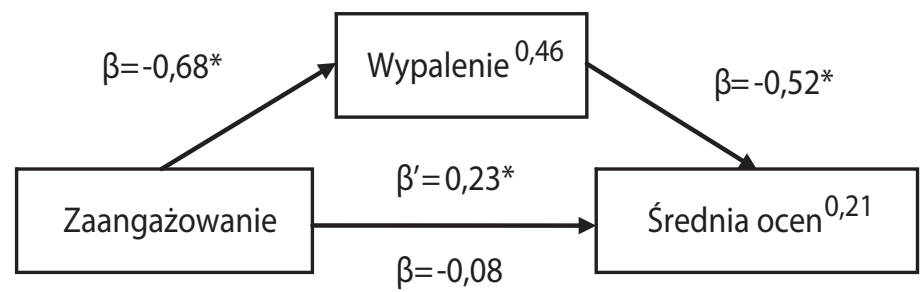

Rysunek 1. Model związków pomiędzy wypaleniem studiami, zaangażowaniem w studia i średnią ocen, $\beta$ - standaryzowany współczynnik regresji, $\beta$ ' - $\beta$ dla związku zaangażowanie - średnia ocen bez uwzględnienia wypalenia, indeksy górne - współczynniki determinacji R2, *p<0,001 Źródło: Opracowanie własne.

Hipoteza 2a Studenci zdający wszystkie egzaminy w pierwszym terminie cechują się wyższym poziomem zaangażowania w studia niż studenci, którzy nie zdali wszystkich egzaminów w pierwszym terminie.

Hipoteza2b Studenci zdający wszystkie egzaminy w pierwszym terminie cechują się niższym poziomem wypalenia studiami niż studenci, którzy nie zdali wszystkich egzaminów w pierwszym terminie.

W celu zweryfikowania postawionych hipotez badawczych sprawdzono różnice w poziomach wypalenia i zaangażowania pomiędzy studentami, którzy zdali wszystkie egzaminy w pierwszym terminie, i studentami, którzy nie zdali wszystkich egzaminów w pierwszym terminie. Wyniki przeprowadzonych analiz zawiera tabela 4. 
Tab. 4. Porównanie średniego poziomu wypalenia studiami i zaangażowania w studia pomiędzy studentami, którzy zdali wszystkie egzaminy w pierwszym terminie (zdali), i studentami, którzy nie zdali wszystkich egzaminów w pierwszym terminie (nie zdali) (test t studenta)

\begin{tabular}{lcccccccc}
\hline & $\begin{array}{c}\text { M } \\
\text { zdali }\end{array}$ & $\begin{array}{c}\text { M nie } \\
\text { zdali }\end{array}$ & $\begin{array}{c}\text { SD } \\
\text { zdali }\end{array}$ & $\begin{array}{c}\text { SD nie } \\
\text { zdali }\end{array}$ & t & df & p & $\begin{array}{c}\text { d Co- } \\
\text { hena }\end{array}$ \\
\hline Wypalenie & 23,3 & 27,7 & 9,3 & 8,5 & $-2,76$ & 153 & 0,007 & 0,49 \\
\hline Zaangażowanie & 30,3 & 26,9 & 13,0 & 14,1 & 1,44 & 153 & 0,152 & 0,25 \\
\hline
\end{tabular}

M - średnia, SD - odchylenie standardowe

Źródło: Opracowanie własne.

Poziom zaangażowania w studiowanie nie różnił się $(\mathrm{p}=0,152)$ w zależności od tego, czy badani studenci zdali wszystkie egzaminy w pierwszym terminie czy nie (por. tab. 2). Zatem nie możemy potwierdzić hipotezy 2a.

Dalsze analizy (por. tab. 2) wskazują, iż średni poziom wypalenia studiami jest $(\mathrm{p}=0,007)$ niższy w grupie studentów, którzy zdali wszystkie egzaminy w pierwszym terminie ( $M=23,3$; SD 9,3), niż w grupie studentów, którzy nie zdali wszystkich egzaminów ( $M=27,7$; SD 8,5). Zatem na poziomie istotności $\alpha=0,05$ możemy przyjąć hipotezę 2b, stanowiącą, iż studenci zdający wszystkie egzaminy w pierwszym terminie cechują się niższym poziomem wypalenia studiami niż studenci, którzy nie zdali wszystkich egzaminów w pierwszym terminie. W celu dalszej szczegółowej analizy związku wypalenia studiami z liczbą egzaminów zdanych w pierwszym terminie sprawdzono różnice w wynikach uzyskiwanych przez badanych w poszczególnych wymiarach wypalenia (por. tab. 3).

Tab. 5. Porównanie średniego poziomu cynizmu, poczucia braku osiągnięć oraz wyczerpania pomiędzy studentami, którzy zdali wszystkie egzaminy w pierwszym terminie (zdali), i studentami, którzy nie zdali wszystkich egzaminów w pierwszym terminie (nie zdali) (test t studenta)

\begin{tabular}{lcccccccc}
\hline & $\begin{array}{c}\text { M } \\
\text { zdali }\end{array}$ & $\begin{array}{c}\text { M nie } \\
\text { zdali }\end{array}$ & $\begin{array}{c}\text { SD } \\
\text { zdali }\end{array}$ & $\begin{array}{c}\text { SD nie } \\
\text { zdali }\end{array}$ & t & df & p & $\begin{array}{c}\text { d Co- } \\
\text { hena }\end{array}$ \\
\hline Cynizm & 9,05 & 9,68 & 4,98 & 4,87 & $-0,73$ & 152 & 0,468 & 0,13 \\
\hline $\begin{array}{l}\text { Poczucie braku } \\
\text { osiągnięć }\end{array}$ & 5,08 & 7,38 & 3,13 & 3,27 & $-4,16$ & 152 & 0,000 & 0,72 \\
\hline Wyczerpanie & 9,20 & 10,79 & 4,19 & 3,87 & $-2,23$ & 152 & 0,027 & 0,39 \\
\hline
\end{tabular}

Źródło: Opracowanie własne.

Analiza danych pozwala stwierdzić, iż badani zdający wszystkie egzaminy w pierwszym terminie różnili się średnim poziomem wyczerpania $(\mathrm{p}=0,027)$ oraz nasileniem poczucia braku osiągnięć $(\mathrm{p}<0,001)$ w porównaniu $\mathrm{z}$ badanymi, którzy 
nie zdali wszystkich egzaminów w pierwszym terminie, natomiast nie różnili się poziomem cynizmu wobec studiów.

\section{WNIOSKI I DYSKUSJA}

Głównym celem prowadzonych badań była analiza zależności pomiędzy zaangażowaniem w studiowanie i wypaleniem studiami a osiągnięciami akademickimi, mierzonymi jako średnia ocen i liczba egzaminów zdanych w pierwszym terminie. Zakładano, iż: wzajemne oddziaływanie zaangażowania w studiowanie i wypalenia studiami jest predyktorem średniej ocen uzyskiwanych przez studentów (hipoteza 1); studenci zdający wszystkie egzaminy w pierwszym terminie cechują się wyższym poziomem zaangażowania w studia niż studenci, którzy nie zdali wszystkich egzaminów w pierwszym terminie (hipoteza 2a); studenci, zdający wszystkie egzaminy w pierwszym terminie cechują się niższym poziomem wypalenia studiami niż studenci, którzy nie zdali wszystkich egzaminów w pierwszym terminie (hipoteza 2b).

Hipotezy 1 nie potwierdzono. Nie wykazano, by wzajemne oddziaływanie zaangażowania w studiowanie i wypalenia studiami bezpośrednio wiązało się ze średnią ocen. Wskazano natomiast na możliwą mediacyjną rolę wypalenia w relacji zaangażowanie - oceny. Zaangażowanie w studiowanie negatywnie wiąże się z wypaleniem i przez to może pośrednio pozytywnie wiązać się ze średnią ocen. Hipotezy 2a również nie potwierdzono, studenci zdający wszystkie egzaminy w pierwszym terminie nie różnili się poziomem zaangażowania w studia od studentów, którzy nie zdali wszystkich egzaminów w pierwszym terminie. Hipotezę 2b potwierdzono. Studenci, którzy zdali wszystkie egzaminy w pierwszym terminie, charakteryzowali się niższym poziomem wypalenia niż studenci, którzy nie zdali wszystkich egzaminów w pierwszym terminie. Szczegółowe analizy wykazały różnicę w poziomie wyczerpania i braku poczucia osiągnięć oraz brak różnicy w poziomie cynizmu.

Odpowiadając na pytanie, w jaki sposób zaangażowanie w studia i wypalenie studiami wiążą się z osiągnięciami akademickimi, można stwierdzić, iż wypalenie studiami istotnie i negatywnie wiąże się z osiągnięciami akademickimi, podczas gdy poziom zaangażowania w studiowanie nie wiąże się bezpośrednio z osiągnięciami akademickimi. Wypalenie studiami jest istotnym predyktorem średniej ocen tłumaczącym ok. 20\% jej zmienności. Związek zaangażowania w studiowanie ze średnią ocen jest pośredni - mediowany poprzez poziom wypalenia studiami. Zaangażowanie negatywnie wiąże się z wypaleniem studiami, a jego zmiennością można tłumaczyć ok. 46\% zmienności w zakresie wypalenia. 
Uzyskane rezultaty wydają się przeczyć potocznemu przekonaniu, iż zaangażowani studenci to studenci odnoszący sukcesy w nauce (Dunne, Owen, 2013). Wśród badanych studentów zaangażowanie - energia do nauki, przekonanie, że studia są wartościowe i inspirujące (Schufeli i in., 2002) - nie wykazywało bezpośredniego związku ze średnią ocen i liczbą zdanych egzaminów. Związek taki wykazało natomiast wypalenie studiami. Średnia ocen negatywnie wiązała się z poziomem wypalenia, a studenci, którzy zdali wszystkie egzaminy w pierwszym terminie, prezentowali niższy poziom wypalenia studiami niż ci, którzy nie zdali egzaminów w pierwszym terminie. Wyniki badania uwidaczniają zatem negatywny związek wypalenia studiami z osiągnięciami akademickimi. Można pokusić się o konkluzję, iż z sukcesem akademickim silniej wiąże się brak wypalenia studiami niż obecność zaangażowania w studiowanie.

Wykształceni ludzie przyczyniają się do poprawy jakości życia nie tylko swojego, ale także społeczności, w których żyją (Gerber, Manskemp, Schlechter, 2013). Należy zatem dokładać starań, by umożliwić studentom odnoszenie sukcesów. Wyniki przeprowadzonych badań wskazują, że szczególną uwagę należałoby przykładać do minimalizowania wypalenia studiami. W tym kontekście warto zwrócić uwagę, iż wśród osób, które nie zdały wszystkich egzaminów w pierwszym terminie, obserwowano istotnie niższy poziom poczucia własnej skuteczności niż u studentów, którzy zdali wszystkie egzaminy w pierwszym terminie. Wyniki takie wydają się zbieżne z dotychczasowymi doniesieniami o silnym związku poczucia skuteczności zarówno z motywacją (Prat-Sala, Redford, 2010), jak i z ocenami uzyskiwanymi przez studentów (Richardson, Abraham, Bond, 2012). Zatem działania ukierunkowane na minimalizowanie wypalenia mogłyby w pierwszej kolejności skupiać się na kształtowaniu w studentach poczucia własnej skuteczności - przekonania, że warto i można osiągać sukces w nauce (Artino, 2012; Harrison, Rainer, Hochwarter, Thompson, 1997). Ponadto, jak wskazują Alarcon, Edwards i Menke (2011), by skutecznie chronić studentów przed wypaleniem, należy przekazywać im nie tylko wiedzę naukową, ale także wiedzę o skutecznych i nieskutecznych strategiach radzenia sobie z trudnościami, jakie pojawiają się podczas studiowania. Do minimalizowania wypalenia warto dążyć nie tylko ze względu na jego negatywny związek z sukcesami studentów, ale także dlatego, iż jak wykazano w badaniach longitudinalnych (Salmela-Aro, Savolainen, Holopainen, 2009), wypalenie studiami może mieć poważne konsekwencje zdrowotne - jest istotnym predyktorem symptomów depresyjnych.

Dodatkowym wnioskiem z przeprowadzonych badań może być spostrzeżenie, iż średnia ocen i liczba zdanych egzaminów to wskaźniki, które słabo odzwierciedlają zaangażowanie w studiowanie - zainteresowanie studiami, entuzjazm, pasję 
i dumę z powodu studiów. Wnioski takie w pewien sposób wydają się zgodne z rezultatami badań Chamorro-Premuzic i Furnham (2008), którzy dowodzą, iż wysoka średnia ocen wiąże się zarówno z nastawieniem na zrozumienie materiału i czerpanie przyjemności z nauki, jak i z nastawieniem na osiąganie wysokich stopni ze względu na różnorodne nagrody, jakie się z dobrymi ocenami wiążą. Wysoka średnia ocen odzwierciedlać może zatem raczej skuteczność strategii nauki przyjętej przez studenta niż autentyczne zainteresowanie przedmiotem studiów. Powstaje tu pytanie, czy tak duże znaczenie średniej (por np. UJ, 2014; UW, 2014) w definiowaniu osiągnięć studentów jest uzasadnione. Z drugiej strony, jak nagradzać i cenić zaangażowanie w studiowanie, jeśli nie wiąże się ono z obiektywnymi wynikami w postaci ocen i zdanych egzaminów? Rezultaty przeprowadzonych badań, oprócz dostarczania nowej wiedzy o związku zaangażowania i wypalenia z średnią ocen i zdanymi egzaminami, zwracają także uwagę na potrzebę refleksji nad tym, czym są osiągnięcia akademickie i jak należałoby je definiować.

Przeprowadzone badania nie są wolne od ograniczeń, a ich wynik należy traktować $\mathrm{z}$ należytą ostrożnością. $\mathrm{W}$ dalszych badaniach warto podjąć próbę przeprowadzenia analiz longitudnalnych obejmujących pomiary na kolejnych etapach studiowania, które mogłyby pomóc zweryfikować wykazane zależności. Wyniki badań nie mogą być także generalizowane na całą populację studentów, badani byli jedynie studenci korzystający z Internetu i portalu Facebook. Mimo swoich ograniczeń wyniki przeprowadzonego badania wydają się dostarczać nowej i oryginalnej wiedzy o zjawiskach zaangażowania i wypalenia studiami oraz ich związku z osiągnięciami akademickimi.

\section{Literatura:}

Alarcon, G.M., Edwards, J.M., Menke, L.E. (2011). Student Burnout and Engagement : A Test of the Conservation of Resources Theory. The Journal of Psychology, 145 (3), s. 211-227.

Artino, A.R. (2012). Academic self-efficacy: from educational theory to instructional practice. Perspectives on Medical Education, 1, s. 76-85.

Bakker, A.B., Demerouti, E. (2014). The Job Demands-Resources Theory. W: P.Y. Chen, C.L. Cooper (red.), Work and Wellbeing: A Complete Reference Guide, Volume III (s. 37-65). West Sussex: John Wiley \& Sons.

Bakker, A.B., Sanz Vergel, A.I., Kuntze, J. (2014). Student engagement and performance: A weekly diary study on the role of openness. Motivation and Emotion, 39(1), s. 49-62. Baron, R.M., Kenny, D. (1986). The moderator-mediator variable distinction in social psychological research: conceptual, strategic, and statistical considerations. Journal of Personality and Social Psychology, 51 (6), s. 1173-1182. 
Batorski, D. (2013). Polacy wobec technologii cyfrowych - uwarunkowania dostępności i sposobów korzystania. Diagnoza Społeczna 2013 Warunki i Jakość Życia Polaków - Raport, Contemporary Economics, 7, s. 317-341.

Bedyńska, S., Książek, M. (2012). Statystyczny drogowskaz 3, Praktyczny przewodnik wykorzystania modeli regresji oraz równań strukturalnych. Warszawa: Wydawnictwo Akademickie Sedno.

CBOS (2014). Komunikat z badań - Internauci 2014. Pobrano z: http://www.cbos.pl/ SPISKOM.POL/2014/K_082_14.PDF.

Chamorro-Premuzic, T., Furnham, A. (2008). Personality, intelligence and approaches to learning as predictors of academic performance. Personality and Individual Differences, 44 (7), s. 1596-1603.

Chirkowska-Smolak, T., Kleka, P. (2011). The Maslach Burnout Inventory-General Survey: validation across different occupational groups in Poland. Polish Psychological Bulletin, 42 (2), s. 86-94.

Dunne, E., Owen, D. (2013). The Student Engagement Handbook: Practice In Higher Education. Bingley: Emerald Group Publishing Limited.

Fredricks, J.A., Blumenfeld, P.C., Paris, A.H. (2004). School engagement: Potential of the concept, state of the evidence. Review of Educational Research, 74, s. 59-109.

Gerber, C., Manskemp, N., Schlechter, A. (2013). Investigating the moderating effect of student engagement on academic performance. Acta Academica, 45 (4), s. 256-274.

Harrison, W., Rainer, R.K., Hochwarter, W., Thompson, K.R. (1997). Testing the self-efficacy-performance linkage of social-cognitive theory. The Journal of Social Psychology, 137, s. 79-87.

Hazel, C.E., Vazirabadi, G.E., Albanes, J. Gallagher, J. (2014). Evidence of convergent and discriminant validity of the Student School Engagement Measure. Psychological Assessment, 26 (3), s. 806-814.

Hu, Q., Schaufeli, W.B. (2009). The factorial validity of the Maslach Burnout Inventory - Student Survey in China. Psychological Reports, 105 (2), s. 394-408.

Janosz, M., Archambault, I., Morizot, J., Pagani, L.S. (2008). School engagement trajectories and their differential predictive relations to dropout. Journal of Social Issues, 64 (1), s. 21-40.

Jung-Sook, L. (2014). The Relationship Between Student Engagement and Academic Performance: Is It a Myth or Reality? The Journal of Educational Research, 107 (3), s. $177-185$.

Leacha, L., Zepkea, N. (2011). Engaging students in learning: a review of a conceptual organizer. Higher Education Research \& Development, 30 (2), s. 193-204.

Maroco, J., Bonini Campos, J.A.D. (2012). Defining the Student Burnout Construct: a Structural Analysis From Three Burnout Inventories. Psychological Reports, 111 (3), s. 814-830.

Maslach, C., Schaufeli, W.B., Leiter, M.P. (2001). Job burnout. Annual Review of Psychology, 52, s. 397-422.

Prat-Sala, M., Redford, P. (2010). The interplay between motivation, self-efficacy, and approaches to studying. The British Journal of Educational Psychology, 80 (2), s. 283-305. 
Richardson, M., Abraham, C., Bond, R. (2012). Psychological correlates of university students' academic performance: a systematic review and meta-analysis, Psychological Bulletin, 138 (2), s. 353-387.

Salanova, M., Schaufeli, W., Martinez, I., Breso, E. (2010). How obstacles and facilitators predict academic performance: the mediating role of study burnout and engagement. Anxiety, Stress, and Coping, 23 (1), s. 53-70.

Salmela-Aro, K., Upadyaya, K. (2014). School burnout and engagement in the context of demands-resources model. The British Journal of Educational Psychology, 84 (1), s. 137.

Salmela-Aro, K., Savolainen, H., Holopainen, L. (2009). Depressive symptoms and school burnout during adolescence: Evidence from two cross-lagged longitudinal studies. Journal of Youth and Adolescence, 38 (10), s. 1316-1327.

Schaufeli, W.B., Bakker, A.B. (2004). Job demands, job resources and their relationship with burnout and engagement: A multi-sample study. Journal of Organizational Behavior, 25, s. 293-331.

Schaufeli, W.B. Martinez, I.M. Pinto, M., Salanova, M., Bakker, B. (2002). Burnout and Engagement in University Students: A Cross-National Study. Journal of Cross-Cultural Psychology, 33 (5), s. 464-481.

Schaufeli, W., Taris, T. (2005). The conceptualization and measurement of burnout. Common ground and worlds apart. Work \& Stress 19 (3), s. 256-262.

Schaufeli, W., Leiter, M.P., Maslach, C. (2009). Burnout: 35 years of research and practice. Career Development International, 14 (3), s. 204-220.

Schaufeli, W.B., Bakker, A.B., Salanova, M. (2006). The measurement of work engagement with a short questionnaire: A cross-national study. Educational and Psychological Measurement, 66 (4), s. 701-716.

Stieger S., Reips, U.D., Voracek, M. (2007). Forced-response in online surveys: Bias from reactance and an increase in sex-specific drop out, Journal of the American Society for Information Science and Technology, 58 (11), s. 1657-1658.

Szabowska-Walaszczyk, A., Zawadzka A., Wojtaś M. (2011). Zaangażowanie w pracę i jego korelaty: adaptacja skali UWES autorstwa Schaufeliego i Bakkera. Psychologia Jakości Życia, 10 (1), s. 57-74.

Trowler, V., Trowler,P. (2010). Student engagement evidence summary. NewYork: Higher Education Academy.

UJ, (2014). Zarządzenie nr 90 Rektora Uniwersytetu Jagiellońskiego z 17 września 2014 roku. Pobrane z: http://www.bip.uj.edu.pl/documents/1384597/64923073/ zarz_90_2014.pdf.

UW, (2014). Monitor Uniwersytetu Warszawskiego z dnia 30 września 2014 r. Zarządzenie nr 36 Rektora Uniwersytetu Warszawskiego z dnia 30 września 2014 r. Pobrane z: http://www.bss.uw.edu.pl/aktualnosci/M.2014.197.Zarz.36.pdf.

Vasalampi, K., Salmela-Aro, K., Nurmi, J.E. (2009). Adolescents' self-concordance, school engagement, and burnout predict their educational trajectories. European Psychologist, 14, s. 332-341.

Wang, M. Te, Degol, J. (2014). Staying Engaged: Knowledge and Research Needs in Student Engagement. Child Development Perspectives, 8 (3), s. 137-143. 
Yang, H.J. (2004). Factors affecting student burnout and academic achievement in multiple enrollment programs in Taiwan's technical-vocational colleges. International Journal of Educational Development, 24 (3), s. 283-301.

Zhang, Y., Gan, Y., Cham, H. (2007). Perfectionism, academic burnout and engagement among Chinese college students: A structural equation modeling analysis. Personality and Individual Differences, 43 (6), s. 1529-1540. 